\title{
СИНТЕЗ И ИЗУЧЕНИЕ СВОЙСТВ ЗОЛОТЫХ НАНОКЛАСТЕРОВ И ИХ КОМПЛЕКСОВ С ПРОТИВООПУХОЛЕВЫМ АНТИБИОТИКОМ ДОКСОРУБИЦИНОМ
}

\author{
А.В. Абдуллина, Н.С. Мелик-Нубаров \\ Химический факультет МГУ имени М.В. Ломоносова, \\ 119991, Россия, Москва, Ленинские горы, 1, стр.3
}

DOI:10.19163/MedChemRussia2021-2021-534_E-mail:vasilia.abdullina@chemistry.msu.ru

Доксорубицин - антибиотик, проявляющий высокую противоопухолевую активность [1]. Препарат являетсякардиотоксичным, поэтому актуальна задача минимизации вреда от него, что достигается путем фиксации доксорубицина на носителе, нанокластерах золота (ЗНК), стабилизируемых природным трипептидомглутатионом. Изучение возможности образования комплексов доксорубицин-ЗНК является целью данной работы.

Глутатионовые ЗНК отличаются высокой биосовместимостью и проявляют флуоресцентные свойства $[2,3]$. Используемый в качестве стабилизатора глутатион обеспечивает избыток отрицательного заряда на ЗНК и делает возможным взаимодействие ЗНК и гидрофобной катионной частицы доксорубицина.

В работе были изучены оптические свойства глутатионовых ЗНК в водной бессолевой среде, выявлено отсутствие четкой полосы поглощения (возбуждение на широкой полосе УФ-области спектра), чему соответствует флуоресценияглутатионовых ЗНК на $\lambda \sim 400$ нм. Выявлено, что при добавлении нанокластеров к доксорубицину происходит тушение его флуоресценции. Можно полагать, что этот эффект вызван концентрационным самотушением флуоресценции доксорубицина, иможет являться мерой связывания антибиотика с ЗНК. Эффективная константа диссоциации образующегося комплекса в бессолевой среде, составила 20 мкМ, а в присутствии физиологической ионной силы увеличилась почти на порядок. Цитотоксичность исследовали на клетках аденокарциномы молочной железы человека MCF-7/ADR, резистентной к антибиотику. Для оценки токсичности использовали МТT-тест. Оказалось, что нанокластеры были нетоксичны для этих клеток, а цитотоксичностьдоксорубицина и его комплекса с ЗНК практически не отличалась.

\section{Литература}

[1] Moro S., Beretta L.G, Ben D.D., Nitiss J., Palumbo M., Capranico G. Interaction Model for Anthracycline Activity against DNA Topoisomerase II. Biochemistry. 2004, 43, 7503-7513.

[2] S. Palmal, N.R. Jana. Gold nanoclusters with enhanced tunable fluorescence as bioimaging probes. Wiley Interdiscip. Rev. Nanomed. Nanobiotechnol., 2013, 6, 102-110.

[3] Y. Negishi, K. Nobusada, T. Tsukuda. Glutathione-Protected Gold Clusters Revisited: Bridging the Gap between Gold(I)-Thiolate Complexes and Thiolate-Protected Gold Nanocrystals. J. Am. Chem. Soc. 2005, 127, 5261-5270. 